Original Article

\title{
Quality of life of people with non communicable diseases
}

\author{
Anju Rose ${ }^{1}$, Shashidhara Y.N. ${ }^{2} \&$ Manjula ${ }^{3}$ \\ Manipal College of Nursing M anipal, M anipal University, India. \\ Correspondence \\ Shashidhara Y.N. \\ Associate Professor \& HOD, Department of Community Health Nursing, \\ Manipal College of Nursing M anipal, M anipal University, India. \\ E-mail : shashidhara.yn@manipaledu,
}

${ }^{1}$ M Sc Nursing Student, ${ }^{2}$ Associate Professor \& HOD, ${ }^{3}$ Assistant Professor Department of Community Health Nursing,

\begin{abstract}
Hypertension, Diabetes mellitus or both and asthma are very common chronic diseases among Indian rural population which needs continuous monitoring and treatment. Knowledge on disease management, lifestyle, and health care facilities are available which will have direct impact on their Quality of Life.
\end{abstract}

Purpose: Purpose of the study was to identify the quality of life of people living with non-communicable diseases. The study will be helpful to provideneed based care and to develop strategies to improve quality of life of community.

Methods: A descriptive survey to assess the quality of life of people with non-communicable diseases measured by using WHO QOL BREF scale through interview method. Purposive sampling technique was used to select 200 subjects from selected villages of Udupi District.

Result: showed that majority of subjects felt their quality of life was good [M edian=4, IQR=3-4]. Majority of subjects [median=3, $I Q R=3-4]$ were neither satisfied nor dissatisfied towards their health. Compare to other domains psychological domain has M edian=20, IQR=19-21 represents low quality of life. Overall quality of life of subjects with median $=93$ and IQR $=89$ - 98 represents good quality of life. Analysis based on diseases showed that people with diabetes mellitus had good quality of life as compared with people with other diseases. There was significant association between quality of life of subjects and age, education, occupation and marital status $(P \varangle 0.05)$.

Conclusion: Study concluded that majority of the subjects were perceived their quality of life was good especially with those who have diagnosed as diabetes mellitus.

Keywords: Asthma, Diabetes mellitus, domains, Hypertension, quality of life

\section{Introduction}

Knowledge on disease management, lifestyle, and health care facilities available will have direct impact on their Quality of Life. Quality of services provided will enhance quality of life of the people especially with chronic noncommunicable diseases. A research on people's perception towards their quality of life becomes an essential tool to enhance quality of care. ${ }^{1}$

\begin{tabular}{|c|}
\hline Access this article online \\
\hline Quick Response Code \\
\hline
\end{tabular}

Gholami A, Azini M, Borji

A, Shirazi F, Sharafi Z, Zarei

E conducted a cross sectional study to evaluate QOL in type 2 diabetic patients among 1847 people of Iran by using Iranian version of WHO
QOL BREF scale. Mean age of subjects were $59.65 \pm 12.3$ years and majority were females. Overall Cronbach's alpha was 0.93 , total mean score was 12.18 . The lowest score was found in psychological domain [11.93] and highest in social domain [12.66].Backward multiple regression model showed that education, marital status and household income were significantly associated with all domains of WHOQOL BREF $[p<0.05]$. Study concluded that QOL of patients were moderate to low, so international programmes were necessary to improve QOL. ${ }^{2}$

By reviewing the literature and researcher's personal experience it was felt to assess the quality of life of people living with non-communicable diseases. The aim of the study is to determine the quality of life of people at selected villages. This descriptive survey will help to 
enhance the quality of care and strengthen or develop new strategies; which will enhance the quality of life of the community.

Purpose of the study was to identify the quality of life of people living with non-communicable diseases. The study will be helpful to provide need based care and to develop strategies to improve quality of life of community.

Objectives of the study were to assess quality of life of people living with non-communicable diseases as measured by WHO QOL BREF scale and to find association between quality of life of people living with noncommunicable diseases and selected variables.

In the present study subjects with asthma, hypertension, diabetes mellitus and both hypertension and diabetes mellitus are selected to assess quality of life.

\section{Materials and Methods}

A descriptive survey was done among 200 people with asthma, hypertension, diabetes mellitus and both hypertension and diabetes mellitus within 30-80 years of age.

Subjects were selected from Athrady and Hirebettu villages through purposive sampling technique.

A demographic proforma was used to identify the basic information regarding subjects, which includes 15 items such as age, gender, education, occupation, marital status, religion, monthly family income, preferable health centre, frequency of visits to clinic, type of clinic, diseases and type of health insurance.

WHO Quality of Life BREF scale is a standardized tool consists of 26 items comprised in 4 domains such as physical, psychological, social and environmental. This tool produces four domain scores and two items that examined separately: question 1 asks about an individual's overall perception of quality of life and question 2 asks about an individual's overall perception of his or her health and are scaled in a positive direction (i.e. higher scores denote higher quality of life) ${ }^{(3)}$. Reliability [Cronbach's alpha] was 0.94 on Kannada version of tool.
Data collection was started after obtaining administrative permission from institutional ethical committee Kasturba hospital Manipal, Dean Manipal College of Nursing Manipal, respective Panchayats and informed consent from each person by interviewing them.

\section{Results}

The gathered data was coded and summarized in a master data sheet and then both descriptive and inferential statistics were used to analyze by using SPSS 16.0 version based on objectives and hypothesis.

\subsection{Sample characteristics}

shows that that among 200 subjects, majority were in the age group of 60-69 years (31.5\%), females (71\%), illiterate (33.5\%), Hindu (94.5\%) by religion, unemployed (33\%), having a monthly family income of ' 2936 - ' 4893 (41\%) and belongs to joint family (79.5\%) All (100\%) were visiting any one of the morbidity clinic and most of the subjects were interested to go to private practitioner/ clinic (65\%). Majority $(52.5 \%)$ of subjects were suffering from hypertension

Table 1: Frequency and percentage distribution of sample characteristics $n=200$

\begin{tabular}{lll}
\hline Sample Characteristics & $f$ & $\%$ \\
\hline Age in years: & & \\
Below 50 & 27 & 13.5 \\
$50-59$ & 39 & 19.5 \\
$60-69$ & 63 & 31.5 \\
$70-79$ & 56 & 28 \\
80 and above & 15 & 7.5 \\
Gender: & & \\
Male & 58 & 29 \\
Female & 142 & 71 \\
Educational status: & & \\
Illiterate & 67 & 33.5 \\
Primary school & 44 & 22 \\
Higher primary & 57 & 28.5 \\
High school & 22 & 11 \\
PUC, Diploma, Degree & 10 & 5 \\
Religion: & & \\
Hindu & 189 & 98.5 \\
Muslim & 9 & 45. \\
Christian & 2 & 1 \\
Marital status: & & \\
Married & 131 & 65.5 \\
Widow/ widower & 66 & 33 \\
Separated / divorced & 2 & 1 \\
Unmarried & 1 & 0.5 \\
\hline
\end{tabular}




\begin{tabular}{|c|c|c|}
\hline Sample Characteristics & f & $\%$ \\
\hline \multicolumn{3}{|l|}{ Type of family: } \\
\hline Nuclear & 41 & 20.5 \\
\hline Joint & 159 & 79.5 \\
\hline \multicolumn{3}{|c|}{ M onthly family income in rupees: } \\
\hline '2936-'4893 & 82 & 41 \\
\hline ‘4894-’7322 & 41 & 20.5 \\
\hline ‘7323-'9787 & 39 & 19.5 \\
\hline ‘9788-'19574 & 27 & 13.5 \\
\hline >'19575 & 11 & 5.5 \\
\hline \multicolumn{3}{|l|}{ Visits to clinic: } \\
\hline Yes & 200 & 100 \\
\hline No & 0 & 0 \\
\hline \multicolumn{3}{|l|}{ Type of clinic: } \\
\hline Private practitioner/ clinic & 130 & 65 \\
\hline M CON morbidity clinic & 12 & 6 \\
\hline PHC & 55 & 27.5 \\
\hline All the above & 3 & 1.5 \\
\hline \multicolumn{3}{|l|}{ Frequency of visits: } \\
\hline Once in a month & 61 & 30.5 \\
\hline 2-4 months & 33 & 16.5 \\
\hline 5-7 months & 6 & 3 \\
\hline If any problem & 100 & 50 \\
\hline \multicolumn{3}{|l|}{ Duration of illness (in years) } \\
\hline $1-5$ & 138 & 69 \\
\hline $6-10$ & 34 & 17 \\
\hline $11-15$ & 11 & 5.5 \\
\hline $16-20$ & 10 & 5 \\
\hline $21 \&$ above & 7 & 3.5 \\
\hline \multicolumn{3}{|l|}{ Medications getting from: } \\
\hline M CON morbidity clinic & 15 & 7.5 \\
\hline PHC & 43 & 21.5 \\
\hline M edical shop & 142 & 71 \\
\hline Others & 0 & 0 \\
\hline \multicolumn{3}{|c|}{ Distance from house to clinic in $\mathrm{km}$ : } \\
\hline $0-5$ & 142 & 71 \\
\hline $6-10$ & 38 & 19 \\
\hline $11-15$ & 20 & 10 \\
\hline \multicolumn{3}{|l|}{ Health insurance: } \\
\hline Yes & 114 & 57 \\
\hline No & 86 & 43 \\
\hline \multicolumn{3}{|c|}{ If yes, specify the type of insurance: } \\
\hline M anipal Arogya Card & 37 & 32.45 \\
\hline Konkani Health Card & 27 & 23.68 \\
\hline ESI, Medicare & 40 & 35.08 \\
\hline Others & 10 & 07.77 \\
\hline
\end{tabular}

1.2

$n=2$

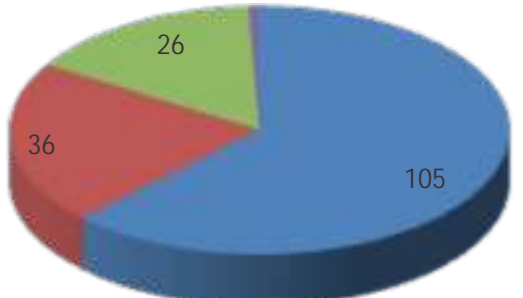

- Hypertension

- Diabetes mellitus

Both DM \& hype

Asthma

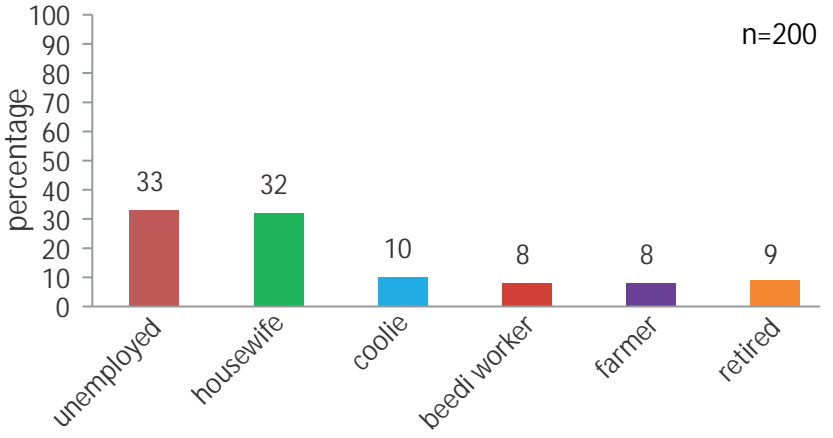

Fig. 2 : percentage distribution of subjects with occupation

\subsection{Description of quality of life of people living with non-} communicable diseases

Quality of life of people living with non-communicable disease such as Asthma, Diabetes mellitus, Hypertension or both Diabetes mellitus and Hypertension assessed by using WHO QOL BREF tool. Maximum score obtained was 124 who were having good quality of life. The findings were depicted in a table 2

Table 2 : Description of scores of overall Quality of life of people living with non-communicable diseases $n=200$

Areas/ domains Maximum Median IQR Minimum Maximum

\begin{tabular}{|c|c|c|c|c|c|}
\hline & $\begin{array}{c}\text { possible } \\
\text { score }\end{array}$ & & & $\begin{array}{l}\text { obtained } \\
\text { score }\end{array}$ & $\begin{array}{l}\text { obtained } \\
\text { score }\end{array}$ \\
\hline $\begin{array}{l}\text { How would you } \\
\text { rate your Quality } \\
\text { of life? }\end{array}$ & 5 & 4 & $3-4$ & 2 & 5 \\
\hline $\begin{array}{l}\text { How satisfied } \\
\text { are you with } \\
\text { your health? }\end{array}$ & 5 & 3 & $3-4$ & 2 & 4 \\
\hline Physical & 35 & 24 & $23-26$ & 17 & 33 \\
\hline Psychological & 30 & 20 & $19-21$ & 13 & 28 \\
\hline Social & 15 & 12 & $9-12$ & 7 & 15 \\
\hline Environmental & 40 & 31 & $31-32$ & 18 & 40 \\
\hline Total quality of life & 130 & 93 & $89-98$ & 64 & 124 \\
\hline
\end{tabular}

It was inferred as majority of subjects felt their quality of life was good [M edian=4, IQR=3-4]. M ajority of subjects [median=3, IQR=3-4] were neither satisfied nor dissatisfied regarding their health. Compared to other domains psychological domain have low quality of life. Overall qualities of life of subjects was good.

Quality of life scores described based on diseases such as Asthma, Hypertension, Diabetes mellitus and both hypertension and diabetes mellitus were well depicted in table 3.

Fig.1 : frequency distribution of subjects based on disease condition 
Table 3 : Disease wise description of scores of QOL of people with non-communicable diseases $n=200$

\begin{tabular}{|c|c|c|c|c|c|c|}
\hline Diseases & Areas/ domains & $\begin{array}{c}\text { Maximum } \\
\text { possible score }\end{array}$ & Median & IQR & $\begin{array}{c}\text { Minimum } \\
\text { Obtained score }\end{array}$ & $\begin{array}{c}\text { Maximum } \\
\text { Obtained score }\end{array}$ \\
\hline $\begin{array}{l}\text { Hypertension } \\
n=105\end{array}$ & $\begin{array}{l}\text { How would you rate your Quality of life? } \\
\text { How satisfied are you with your health? } \\
\text { Physical } \\
\text { Psychological } \\
\text { Social } \\
\text { Environmental } \\
\text { Total quality of life }\end{array}$ & $\begin{array}{c}5 \\
5 \\
35 \\
30 \\
15 \\
40 \\
130\end{array}$ & $\begin{array}{c}4 \\
3 \\
24 \\
19 \\
12 \\
31 \\
93\end{array}$ & $\begin{array}{c}3-4 \\
3-4 \\
23-26 \\
18-21 \\
9-12 \\
31-32 \\
89-97\end{array}$ & $\begin{array}{c}2 \\
2 \\
19 \\
15 \\
7 \\
23 \\
77\end{array}$ & $\begin{array}{l}4 \\
4 \\
32 \\
28 \\
15 \\
37 \\
11\end{array}$ \\
\hline $\begin{array}{l}\text { Diabetes } \\
\text { mellitus } \\
n=36\end{array}$ & $\begin{array}{l}\text { How would you rate your Quality of life? } \\
\text { How satisfied are you with your health? } \\
\text { Physical } \\
\text { Psychological } \\
\text { Social } \\
\text { Environmental } \\
\text { Total quality of life }\end{array}$ & $\begin{array}{c}5 \\
5 \\
35 \\
30 \\
15 \\
40 \\
130\end{array}$ & $\begin{array}{c}4 \\
3 \\
25 \\
20 \\
12 \\
31 \\
93.5\end{array}$ & $\begin{array}{c}3-4 \\
3-4 \\
23-27 \\
19-21 \\
9-12 \\
31-32 \\
92-98\end{array}$ & $\begin{array}{c}3 \\
2 \\
19 \\
18 \\
9 \\
28 \\
85\end{array}$ & $\begin{array}{c}4 \\
4 \\
31 \\
28 \\
15 \\
39 \\
116\end{array}$ \\
\hline $\begin{array}{l}\text { Both } \\
\text { Hypertension } \\
\text { and Diabetes } \\
\text { mellitus } \\
n=26\end{array}$ & $\begin{array}{l}\text { How would you rate your Quality of life? } \\
\text { How satisfied are you with your health? } \\
\text { Physical } \\
\text { Psychological } \\
\text { Social } \\
\text { Environmental } \\
\text { Total quality of life }\end{array}$ & $\begin{array}{c}5 \\
5 \\
35 \\
30 \\
15 \\
40 \\
130\end{array}$ & $\begin{array}{c}4 \\
3 \\
24 \\
20 \\
12 \\
31 \\
93\end{array}$ & $\begin{array}{c}3-4 \\
2-3 \\
22-27 \\
18-22 \\
9-12 \\
29-33 \\
88-101\end{array}$ & $\begin{array}{c}3 \\
1 \\
18 \\
13 \\
9 \\
18 \\
64\end{array}$ & $\begin{array}{c}4 \\
5 \\
33 \\
28 \\
15 \\
40 \\
124\end{array}$ \\
\hline $\begin{array}{l}\text { Asthma } \\
n=33\end{array}$ & $\begin{array}{l}\text { How would you rate your Quality of life? } \\
\text { How satisfied are you with your health? } \\
\text { Physical } \\
\text { Psychological } \\
\text { Social } \\
\text { Environmental } \\
\text { Total quality of life }\end{array}$ & $\begin{array}{c}5 \\
5 \\
35 \\
30 \\
15 \\
40 \\
130\end{array}$ & $\begin{array}{c}4 \\
3 \\
24 \\
19 \\
12 \\
31 \\
93\end{array}$ & $\begin{array}{c}3-4 \\
3-4 \\
22-25 \\
19-20 \\
9-12 \\
30-32 \\
89-95\end{array}$ & $\begin{array}{c}3 \\
3 \\
17 \\
17 \\
8 \\
27 \\
79\end{array}$ & $\begin{array}{c}4 \\
4 \\
33 \\
28 \\
15 \\
36 \\
118\end{array}$ \\
\hline
\end{tabular}

Thus, while comparing each diseases it is inferred as people with diabetes mellitus have good quality of life [median $=93.5$, IQR=9298] than other diseases such as hypertension, asthma or both DM $\&$ hypertension.

\subsection{Association between quality of life of people living with non-communicable diseases and selected variables}

This section deals with association between quality of life and selected demographic variables such as age, gender, occupation, family monthly income, religion, type of clinic and diseases. In order to find out the association, following null hypothesis was stated.

$\mathbf{H O}_{1}$. There will be no significant association between quality of life people living with non-communicable diseases and selected demographic variables.

Table4. Association between Total Quality of Life and selected demographic variables $n=200$

\begin{tabular}{lccccc}
\hline Variables & Below median & Above median & $\chi^{2}$ & df & $p$ value \\
\hline Age in years: & 1 & 16 & & & \\
Below 50 & 15 & 24 & & & \\
$50-59$ & 33 & 30 & 14.847 & 4 & $\mathbf{0 . 0 0 5 *}$ \\
$60-69$ & 40 & 16 & & & \\
$70-79$ & 11 & 4 & & & \\
$80 \&$ above & & & & &
\end{tabular}




\begin{tabular}{|c|c|c|c|c|c|}
\hline Variables & Below median & Above median & $\chi^{2}$ & df & $p$ value \\
\hline \multicolumn{6}{|l|}{ Gender: } \\
\hline Male & 29 & 29 & 0.825 & 1 & 0.364 \\
\hline Female & 81 & 61 & & & \\
\hline \multicolumn{6}{|l|}{ Education: } \\
\hline Illiterate & 38 & 29 & & & \\
\hline Primary school & 30 & 14 & & & \\
\hline Higher primary & 22 & 35 & 13.093 & 6 & $0.042 *$ \\
\hline High school & 14 & 8 & & & \\
\hline PUC \& Diploma \& Degree & 6 & 4 & & & \\
\hline \multicolumn{6}{|l|}{ Occupation: } \\
\hline Unemployed & 47 & 19 & & & \\
\hline House wife & 32 & 32 & & & \\
\hline farmer & 10 & 6 & 15.590 & 5 & $0.008 *$ \\
\hline Coolie & 6 & 10 & & & \\
\hline Beedi worker & 5 & 13 & & & \\
\hline Retired & 9 & 9 & & & \\
\hline \multicolumn{6}{|l|}{ Religion: } \\
\hline Hindu & 107 & 82 & & & \\
\hline Muslim & 3 & 6 & 4.350 & 2 & 0.114 \\
\hline Christian & 0 & 2 & & & \\
\hline \multicolumn{6}{|l|}{ Marital status: } \\
\hline Married & 57 & 74 & & & \\
\hline Widow / widower & 52 & 14 & 23.318 & 3 & $0.001 *$ \\
\hline Separated/divorced & 1 & 1 & & & \\
\hline Unmarried & 0 & 1 & & & \\
\hline \multicolumn{6}{|l|}{ Type of family: } \\
\hline Nuclear & 22 & 19 & 0.037 & 1 & 0.846 \\
\hline Joint & 88 & 71 & & & \\
\hline \multicolumn{6}{|c|}{ Monthly family income in rupees: } \\
\hline $2936-4893$ & 46 & 36 & & & \\
\hline 4894-7322 & 21 & 20 & & & \\
\hline $7323-9787$ & 23 & 16 & 2.267 & 4 & 0.687 \\
\hline 9788-19574 & 16 & 11 & & & \\
\hline$>19574$ & 4 & 7 & & & \\
\hline \multicolumn{6}{|l|}{ Type of clinic: } \\
\hline MCON clinic & 7 & 5 & & & \\
\hline Private clinic/ practitioner & 71 & 59 & 3.953 & 3 & 0.267 \\
\hline $\mathrm{PHC}$ & 32 & 23 & & & \\
\hline All the above & 0 & 3 & & & \\
\hline \multicolumn{6}{|l|}{ Type of diseases: } \\
\hline Hypertension & 60 & 45 & & & \\
\hline Diabetes mellitus & 18 & 18 & 0.575 & 3 & 0.902 \\
\hline Both DM \& Hypertension & 14 & 12 & & & \\
\hline Asthma & 18 & 15 & & & \\
\hline
\end{tabular}

It wasfound that age $\left[\chi^{2}=14.847, p=0.005\right]$, occupation $\left[\chi^{2}\right.$ $=15.590, p=0.008]$, educational status

$\left[\chi^{2}=13.093, p=0.042\right]$ and marital status $\left[\chi^{2}=23.318\right.$, $p=0.001]$ of the people have significant association with their total quality of life. Hence the null hypothesis was rejected with regards to age, occupation, educational status and marital status. So it can be inferred as there is association with one's quality of life and the above said variables 


\section{Discussion}

Description of quality of life of people living with noncommunicable diseases

Present study shows that compare to other domains psychological domain having median $=20, I Q R=19-21$ which can be depicted as low quality of life and environmental domain having a M edian $=31$ and $I Q R=31$ 32 with a maximum obtained score of 40 can be termed as good quality of life.Overall quality of life of subjects with median =93, IQR=89-98 represents good quality of life.

The findings were supported by a study on morbidity profile and quality of life of inmates in old age homes in Udupi district, Md Asadullah et al revealed that most prevalent morbidities were hypertension (47.8\%) and diabetes (43.5\%). The mean score of physical, psychological, social and environmental domains were $53.71 \pm 15.64,58.16 \pm 13.57, \quad 34.66 \pm 14.87$ and $60.46 \pm 10.14$ respectively, where maximum score in environmental domain and minimum in social domain were observed. ${ }^{(4)}$

\section{Association between quality of life of people living with non-communicable diseases and selected variables.}

Present study shows that age $\left[\chi^{2}=14.847, p=0.005\right]$, occupation $\left[\chi^{2}=15.590, p=0.008\right]$, educational status $\left[\chi^{2}=13.093, p=0.042\right]$ and marital status $\left[\chi^{2}\right.$ $=23.318, p=0.001$ ] of the people have significant association with their total Quality of life.

This was supported by B. S. Sathvik et al conducted a study to assess the quality of life in hemodialysis patients using the WHO QOL BREF questionnaire revealed that educational status and family income were associated with their QOL. There was no association between type of

\section{References}

1. Chandwani HR, Jivarajani PJ, Jivarajani HP. Community Perception And Client Satisfaction About The Primary Health Care Services In A Tribal Setting Of Gujarat - India. The Internet Journal of Health. 2009; Volume 9 (2).

2. Gholami A, Azini M , Borji A, Shirazi F, Sharafi Z, Zarei E. Quality of Life in Patients with Type 2 Diabetes: Application of WHOQoL-BREF Scale. ShirazE-M edical Journal. July 2013; Vol. 14 (3).

3. Available at www.who.int.org

4. Asadullah M d, Kunal K, Basavraj K, Sowmya M, Santosh K,Shailesh W, co-morbidities and the type of primary kidney disease on the QOL of hemodialysis subjects. ${ }^{(5)}$

\section{Conclusion}

It was found that majority of subjects felt their quality of life was good. M ajority of subjects were neither satisfied nor dissatisfied towards their health. Compared to other domains psychological domain has Median=20, IQR=1921 which represent low quality of life while environmental domain have good quality of life. People with diabetes mellitus have good quality of life when compared to other diseases such as hypertension, asthma and both diabetes mellitus \& hypertension.

Limitations of the study were The study used non probability purposive sampling, so generalizability of the study was limited and study was limited only to the people living with non-communicable diseases such as asthma, hypertension, diabetes mellitus and both hypertension and diabetes mellitus in adopted villages of Manipal College of Nursing M anipal.

Recommendations of the study are: A comparative study can be undertaken between urban and rural areas to identify the differences in their quality of life, a qualitative study can be done by including all non-communicable diseases present in the selected villages and study can be replicated by using stratified sampling method considering large sampling size.

\section{Acknowledgement}

The authors wish to thank WHO for giving permission and Kannada version of WHO QOL BREF scale and to Dr. Anice George, Dean, Manipal College of Nursing for providing an opportunity to conduct the study.

Padmamohanan. A study on morbidity profile and quality of life of inmates in old age homes in Udupi district, Karnataka, India. International Journal of Basic and Applied Medical Sciences. 2012; Volume 2 (3) September-December, pp.91-97.

5. Sathvik BS, Parthasaradhi G, Narahari M G, Gurudev KC. An assessment of the quality of life in haemodialysis patients using the WHOQOLBREF questionnaire. Indian Journal of Nephrology. 2008; vol 18 (4); pp: 141 149 